\title{
Smell and taste disorders
}

\begin{abstract}
Smell and taste disorders can markedly affect the quality of life. In recent years we have become much better in the assessment of the ability to smell and taste. In addition, information is now available to say something about the prognosis of individual patients. With regard to therapy there also seems to be low but steady progress. Of special importance for the treatment is the ability of the olfactory epithelium to regenerate.
\end{abstract}

Keywords: olfaction, gustation, flavor, anosmia, dysgeusia

\author{
Thomas Hummel ${ }^{1}$ \\ Basile N. Landis ${ }^{2}$ \\ Karl-Bernd Hüttenbrink ${ }^{3}$ \\ 1 University ENT Clinics, \\ Dresden, Germany \\ 2 University ENT Clinics, Bern, \\ Switzerland \\ 3 University ENT Clinics, \\ Cologne, Germany
}

\section{Introduction}

In a recent review [1] three functions were assigned to the senses of smell and taste, namely a warning of danger, interpersonal communication and importance for eating and drinking. These functions reflect the complaints of patients with smell and taste disorders: Patient complaints include loss of "fine taste", inability to detect the odour of a partner or child, and the occurrence of, for example, food poisoning [2], [3], [4], [5].

In general the value of these senses is only recognised when they are lost. It is assumed that about $5 \%$ of people exhibit functional anosmia [6], [7], [8], [9]. This is largely caused by age - above an age of 50 years $25 \%$ of people have an impaired sense of smell [6], [10]. Interestingly, the ability to smell appears to be a measure of the overall health of a person: For example, smell becomes worse the more medicines are taken [8], [11] and one's life expectancy seems to be negatively associated with lowered olfactory abilities [12]. Despite these relationships, relatively little is known about the causes and possible treatments of smell and taste disorders when this is compared to understanding of sight and hearing disorders.

Research in the field of the chemical senses harbours more technical difficulties with controlling olfactory, gustatory or trigeminal stimuli than this is the case for visual and acoustic stimuli. Due to a number of factors, it is much easier to produce clicks of exactly 10 ms duration of a defined pitch than, for example, to generate a peach odour of precise duration, concentration and dispersal rate [13]. Other special aspects arise from the multisensory integration of information, which is very important for smell, taste and trigeminal perception - for example when eating a cherry. The perception of taste results from the interplay of at least three sensory channels, namely 1 . taste, 2 . smell and 3 . the trigeminal sys- tem. (1) The gustatory system (N. glossopharyngeus, $\mathrm{N}$. facialis, N. vagus) recognizes the basic tastes: sweet, sour, salty, bitter and umami (glutamate). (2) The olfactory nerve recognizes a wide range of odorants such as vanilla or H2S (the smell of rotten eggs). When eating, the $\mathrm{N}$. olfactorius identifies all the fine nuances which transform the intake of food into a culinary experience. Here, the odour molecules are passed to the olfactory epithelium via the retronasal pathway. A connoisseur of taste therefore also has a fine sense of smell. (3) Finally, the N. trigeminus identifies sensations such as the sharpness of horseradish, and the cooling, tingling effect of menthol. As almost all odours can cause a trigeminal sensation, the trigeminal nerve plays a key role in the perception of odours.

Other chemo-sensitive systems that have been described for animals, such as the vomeronasal organ [14], [15] and the N. terminalis [16], probably have no importance in adult people.

\section{The sense of smell}

\subsection{Physiology and anatomy}

The olfactory epithelium is located on the roof of the nasal cavity and hence does not lie in the main airflow stream of breathing [17]. This narrow location called olfactory cleft is open for the ortho- but also retronasal airflow. This means odours can reach the olfactory cleft via sniffing through the nostrils but also via the nasopharynx by passing retronasally into the nose when eating or drinking. Due to this special location of the olfactory neuroepithelium, the local odour concentration is partly subject to respiratory control [18]. Also, the complex intranasal anatomical conditions [19] explain why smell disorders can occur after nose operations with 
anatomical changes far from the olfactory regions [20]. There are also particular clinical pictures with patients able to recognize retronasal stimuli but not orthonasal odors - and vice-versa [21], [22].

The olfactory receptor neurons (ORNs) are located in the olfactory epithelium and thus directly exposed to environmental conditions (temperature, toxins, trauma, etc.). This could be a reason why olfactory cells regenerate continuously [23], [24]. This ability to regenerate probably diminishes with increasing age [25], [26], which could be the cause of the increasing susceptibility of the olfactory system to viral diseases and decreased olfactory function with age [27], [28].

Before odours can cause excitation of the olfactory receptors, which are located on cilia on the bipolar olfactory receptor neurons (ORNs), the odour molecules must first diffuse through the mucous on the mucous membrane [29]. The proteins which are dissolved in the mucous, but which have been little studied [30], [31], probably act as transport proteins for lipophilic odours, through the mucous to the receptor. Little is also known about how odours are metabolized within the human olfactory mucous membrane and it is not yet clear if the mucous membrane has local growth factors interacting with the ORN homeostasis [32].

About 1,000 olfactory receptors are coded in the human genome [33], although only about 380 of these receptors are functionally expressed within the human olfactory epithelium [34]. Each ORN expresses a specific receptor type. These receptors are not highly specific to a single odorant, rather single odorants evidently bind to different receptor types. As ORNs that express the same receptor type send their axons to the same glomeruli in the olfactory bulb, the activation of different receptor types causes different excitation patterns in the bulb. These different excitation patterns are the basis for the quality coding of odours. The participation of the hippocampus and the amygdala in the processing of odour information partly explains the emotional character of odours and the key role of odours in the recalling of (typically children's) memory records [35]. The physiology of the cerebral processing of odour impressions is not wholly clear [36], [37]. However, the orbitofrontal cortex plays a major role in the conscious perception of odours [36]; other important structures are the piriform cortex, the amygdala, the hippocampus, the thalamus, the nucleus accumbens, and the cerebellum.

Olfactory sensitivity depends on age and gender. Women are superior to men in virtually all aspects of olfactory function [38]. The exact reason for this is unclear; hormonal effect have been discussed but remain a matter of debate; possibly the higher social awareness of women also plays a role, in so far that women, more than men, show interest in odours as social signals (e.g. body odours, food odours). Accordingly, women on average suffer more than men from loss of smell [5].

The reduced ability to smell with increasing age is long known [10], [39] and is also partly due to the decrease in ORNs [26]. This presbyosmia is, however, not unavoid- able, but is also an expression of overall health [11]; people who have "aged well" and do not take any medication seem to have essentially normal smell thresholds [40]. The slow, age-related loss of smell is however not always noticed or complained about; the loss of "fine taste" is apparently partly offset by gustatory and trigeminal sensations [41], [42].

\subsection{Definition of olfactory disorders}

\section{Quantitative smelling disorders}

Anosmia describes the lack of ability to smell, and specific anosmia describes the inability to smell a specific odour, whereas the vast majority of odors are normally perceived. Such specific anosmias have been described for a series of different odours [43] and are considered a physiological phenomenon. The occurrence of these specific anosmias indicates that specific receptors are necessary for perceiving a specific odour [44]. Specific anosmias have little clinical importance. The term functional anosmia refers to a significantly reduced ability to smell, although some smell sensations can be present. These do however not give patients a normal ability to smell which would be meaningful in daily life. Hyposmia refers to a reduced ability to smell, and hyperosmia to an enhanced ability to smell. Hyposmic conditions are common, but hyperosmias are very rare; they have been encountered, for example, after exposure to toxic vapours [45] and with migranes [46].

\section{Qualitative smell disorders}

A distinction is made here between parosmia and phantosmia. The latter describes the perception of odours in the absence of a relevant odour source, and the former describes the qualitative "wrong" perception of odours. Patients, for example, perceive something after being presented with an odour of roses, which it is not the expected odour of roses, but rather a distorted and often undefined odorous perception. Exactly the same odour is also perceived by parosmia patients after being presented other odours, meaning that many odours qualitatively smell more or less the same. In general these "other" odour sensations are experienced as unpleasant. And they are generally only described in vague terms, for example as "chemical". Parosmia is typically associated with reduced olfactory sensitivity. It can occur after viral infections of the upper respiratory tract or after skull-brain traumas. In rare cases parosmia can be caused by sinusitis by odours which arise in the infected paranasal sinuses. Many patients having qualitative smell disorders are also found to simultaneously have symptoms of depression (overview in [47]).

A simple classification of qualitative smell disorders can be made based on 3 criteria: daily/not daily ( 1 or 0 points resp.); intense/not intense (1 or 0 points resp.); social or other notable consequences (e.g. weight increase/loss)/no social or other consequences (1 or 0 
points resp.): The sum of the points gives the degree of parosmia or phantosmia (0 to 3rd degree) [48]. The graduation of parosmia was recently investigated for its clinical usefulness by means of a questionnaire. This first study appears very promising and a further improved questionnaire about clinical parosmia and phantosmia is in preparation [49].

Many patients with smell disorders who visit special clinics also complain of a loss of taste [50]. Only about $10 \%$ of the patients complain of an isolated loss of taste; there is however only a measurable loss of taste in less than $5 \%$ of these patients [50]. On the other hand, a loss of smell is generally accompanied by a slight reduction in the ability to taste, probably due to the lack of central nervous system interactions between the chemical senses [51], [52]; see also [53].

\subsection{Aetiology of olfactory disorders}

The four main causes of smell disorders are (1) trauma, (2) viral infections, (3) nasal causes such as sinusitis or polyposis nasi and (4) smell disorders associated with aging or neurological illnesses such as Parkinson's disease or Alzheimer's disease. Smell disorders after a trauma are possible due to severance of the fila olfactoria [54], and probably also the contusion of secondary olfactory-related areas of the brain such as the orbitofrontal cortex [55]. Viral infections are assumed to cause damage to the ORNs [56]. However, the triggering agent is still unclear [57], [58].

With nasal causes one assumes an inflammation-related functional impairment or shift of the mechanical access to the olfactory epithelium [59], [60]. One of the first symptoms of both Alzheimer's disease [61] and also Parkinson's disease [62], [63] is a decrease in olfactory sensitivity. Interestingly, this precedes the motoric symptoms of Parkinson's disease by 4-6 years (Table 1 , Table 2).

\section{Smell disorders accompanying neurological illnesses}

Smell disorders accompany many neurodegenerative illnesses [64], [65] and are important for their early and differential diagnosis. They are present in over 95\% of patients with idiopathic Parkinson's syndrome (IPS) [66] - if one uses the smell function of young, healthy persons as the standard value. When using age-related standard values [67] almost $75 \%$ of IPS patients can still be diagnosed with an olfactory dysfunction (Table 2). Here, the majority of the patients have severe hyposmia, or already anosmia. For this reason, the diagnosis of IPS should be reconsidered in patients with a normal ability to smell suspected to suffer from IPS. The loss of smell occurs very early during the progression of IPS, meaning that it can be considered to be the first symptom of the illness. It is suspected that the olfactory disorders precede the motoric symptoms by ca. 4-6 years [62], [66], [68], [69]. The primary cause of the smell disorder accompanying IPS is unknown; with solely non-specific changes in peri- pheral olfactory structures, it is however assumed to involve central brain structures [68], [70].

Smell disorders also occur with other Parkinson's syndromes such as Lewy-Body dementia and multi-system atrophy [71], [72]. Huntington's disease is associated with moderate hyposmia [73]. Mild olfactory disorders have also been described for some heredoataxias and motor neuron diseases [74], [75].

Similarly severe olfactory disorders to those found with IPS have been observed with Alzheimer's disease (AD). Meta analysis of studies carried out up until now on olfactory disorders accompanying AD and IPS showed no differences in the test results of diagnostic use [74]. The smell disorder with AD also represents an early symptom of the disease [76]. Treatment of the olfactory dysfunction associated with neurodegenerative illnesses has hitherto not been possible. Due to its early occurrence with IPS and $A D$ this disorder does however have importance for diagnosing these diseases, namely patients with an unexplained loss of smell have a higher risk of subsequently developing IPS or AD. For this reason, the Guidelines of the "Deutsche Gesellschaft für HNO-Heilkunde" (http:// www.awmf.org/leitlinien/detail/II/017-050.html) state that a neurological examination is recommended for patients with unexplained smell disorders on completion of the ENT diagnostics in the event of there being irregularities in the anamnesis and examination.

There are many other causes of smell disorders, including congenital anosmia, exposure to toxic substances, psychiatric illnesses such as schizophrenia and depression, epilepsy or systemic diseases such as sarcoidosis, lupus erythematodes, as well as endocrine disorders like hypothyroidism, diabetes or isolated organ deficiencies like kidney failure and liver failure or tumors (e.g. esthesioneuroblastoma and other intranasal carcinomas and benign or malignant brain tumours). Latrogenic causes of smell disorders have been cited as neurosurgical operations, radiotherapy, intake of medicines (Table 3 ) and occasionally ENT procedures. Often the cause of the smell disorder cannot be found with certainty; some of the idiopathic dysosmias are due to inflammation [77] or the early onset of Parkinson's disease [66].

\subsection{Patient examination}

The first step is a detailed patient's history (see http:// wwwold.tu-dresden.de/medkhno/riechen_schmecken/ download.htm). This should cover eating, drinking and smoking habits, accidents, operations and medicines taken as well as URTIs preceding the olfactory disorders and the presence of nasal complaints (nasal obstruction, rhinorrhea, facial pain). Questions must also be asked about thyroid function, depression, lupus erythematodes, zinc deficiency, vitamin A or B12 deficiency and allergies. The focus of the physical examination is the ENT examination. The endoscopic examination of the nose must in particular check for polyps or other swellings in the area of the middle turbinate or olfactory cleft region, which can block access of odor molecules to the olfactory epi- 
Table 1:Features of post-trauma, post-viral/infection and sinunasal smell disorders

\begin{tabular}{|l|l|l|l|}
\hline & Skull-brain trauma & $\begin{array}{l}\text { Infection of the upper } \\
\text { respiratory tract }\end{array}$ & Rhinitis/Sinusitis \\
\hline Probable cause & $\begin{array}{l}\text { Lesion of olfactory fibres in } \\
\text { the region of the lamina } \\
\text { cribrosa; Contusion of } \\
\text { important olfactory areas of } \\
\text { the brain }\end{array}$ & $\begin{array}{l}\text { Viral damage to the } \\
\text { olfactory epithelium }\end{array}$ & $\begin{array}{l}\text { Mechanical shifting, } \\
\text { oedema/functional } \\
\text { impairment as a result of } \\
\text { inflammation processes in } \\
\text { the mucous } \\
\text { membrane/olfactory bulb } \\
\text { (?) }\end{array}$ \\
\hline $\begin{array}{l}\text { Occasional smell } \\
\text { sensations }\end{array}$ & Seldom & Frequently & Frequently \\
\hline Epithelium & Degeneration & $\begin{array}{l}\text { Metaplasia, abnormal } \\
\text { development of the ORN }\end{array}$ & Usually normal \\
\hline $\begin{array}{l}\text { Rate of occurrence of smell } \\
\text { disorders }\end{array}$ & About 5\% & About 1\% & $\begin{array}{l}\text { About 2/3 of all patients } \\
\text { with chronic sinusitis }\end{array}$ \\
\hline Typical age & $20-50$ years & Older than 50 years & 30-60 years \\
\hline Onset of smell disorders & Fast & Fast & Slow \\
\hline Loss of smell & Severe & Moderate & Moderate \\
\hline $\begin{array}{l}\text { Rate of occurrence of } \\
\text { parosmia }\end{array}$ & Frequent & Very frequent & Rather seldom \\
\hline $\begin{array}{l}\text { Probability of improvement } \\
\text { of the smell disorder }\end{array}$ & $\begin{array}{l}\text { Less often, improvement } \\
\text { mostly in hyposmia } \\
\text { patients }\end{array}$ & $\begin{array}{l}\text { Often, improvement usually } \\
\text { over several years }\end{array}$ & $\begin{array}{l}\text { Very often, improvement } \\
\text { due to OP or treatment with } \\
\text { corticosteroids, however } \\
\text { often only short-term }\end{array}$ \\
\hline
\end{tabular}

Table 2: Relative degree of olfactory dysfunction associated with neurodegenerative diseases. +++: high degree of smell loss; $0 /(+)$ : no smell loss or slight smell loss.

The majority of the findings are based on studies on small groups of patients.

Disease/illness

Idiopathic Parkinson's disease, Alzheimer's disease, Lewy body dementia, familial Parkinson's disease PARK 8
Relative impairment of the olfactory function

\begin{tabular}{lc} 
Multi system atrophy, Huntington's disease & ++ \\
\hline Motor neuron diseases, Friedreich's ataxia, spinocerebellar ataxia type 2, \\
progressive supranuclear ophthalmoplegia, familial Parkinson's disease \\
PARK 1
\end{tabular}

Table 3: Medicines which may cause smell disorders

\begin{tabular}{|l|l|}
\hline Group & Examples of substances \\
\hline Antibiotics & Streptomycin \\
\hline Antirheumatic drugs & Gold \\
\hline Antihypertonic drugs & Diltiazem, nifedipine \\
\hline Antidepressants & Amitryptyline \\
\hline Chemotherapeutic drugs & Methotrexate \\
\hline Local anaesthetics & Cocaine \\
\hline Opioids & Remifentanil, morphine \\
\hline Psychopharmaceuticals & Amphetamines, alcohol \\
\hline Sympathomimetics & Chronic use of local vasoconstrictive substances \\
\hline Other & Sildenafil \\
\hline
\end{tabular}


thelium meaning the smell function disappears but the ability to breathe is unimpaired. Such a condition has been described and named "olfactory cleft disease" [78], consisting of an isolated obstruction of the olfactory cleft. This is the reason why rhinomanometry is not entirely useful for evaluating smell function (see also [79]).

A neurological consultation is often recommended. MRI examinations may be necessary, for example for idiopathic smell disorders and for cerebral causes of smell disorders such as brain tumours, blood vessel malformation or changes, bleeding or infarctions. Furthermore, MRI is still the gold standard for evaluating congenital smell disorders due to aplasia or hypoplasia of an olfactory bulb.

\subsection{Testing the ability to smell}

\section{Psychophysical testing of orthonasal olfaction}

A distinction must be made between screening tests for orthonasal olfaction and other examination procedures. Tests for screening olfaction must be able to distinguish between "healthy" and "ill". A series of procedures are available for this [80], almost all of which involve identifying odours. The "Sniffin" Sticks" test in its various versions is introduced below. This test is recommended by the Working Group on Olfaction and Gustation of the German Society for ENT Medicine.

The screening test with the reusable "Sniffin' Sticks" [81], [82] involves smelling 12 odours and gives a comprehensive result [83]. There are also shortened tests with 3 [84] or 5 odor probes [85] which give good clinical data but only allow for limited conclusions to be drawn. The odors are distributed in felt-pen like devices. On removal of the cap the odour is released. The pen is held for ca. 3 seconds about $2 \mathrm{~cm}$ under both nostrils. The patients are asked to identify the odour from a list of 4 choices. The procedure is based on a forced choice paradigm. The overall result is the sum of the correct answers.

In addition to the screening tests, standardised and validated tests for detailed assessment of olfaction function have been developed. They allow the assessment of various olfactory functions such as the detection threshold for one or more odours, the ability to discriminate between or to identify odours, or to investigate the smell memory and the ranking of above-threshold odour concentrations. The reason for these diverse tests is the assumption that different tests concern different structures related to the processing of olfactory information ([86], [87], [88], but also see [89], [90]). Sniffin' Sticks permit detailed evaluation of the sense of smell [67]. The test is subdivided into threshold, discrimination and identification tests, with the later two being suprathreshold tests. In order to increase the reliability of the measurements, each patient must choose an answer even if he is not sure or not perceiving any odour at all ("forced choice paradigm"). The threshold test indicates the concentration at which the odour is reliably detected. The odorants most frequently used are n-butanol or phenylethyl alcohol [91], because of their minimal trigeminal components. For this test the patient wears a blindfold. The concentration of the solutions is based on a dilution series of 16 steps starting from a $4 \%$ concentration (dilution 1:2). The patient is passed 3 sticks one after the other. One of these sticks bears the odour, the other two only the odourless solvent. The sequence of the sticks is random. The test person must identify the odour-containing stick. If the patients choice was wrong, the concentration is increased stepwise. As soon as the test person identifies the correct stick two times in a row and hence has exceeded the odour threshold, this represents the first turning point. Now the pen with the next lower concentration is used. The concentration is lowered until the odour threshold is passed through again and the test person can no longer pick out the correct pen. This is then the second turning point. The concentration is then increased again, etc. This procedure is continued until 7 such turning points have been reached. The determination of the odour threshold is calculated as the average of the last 4 turning points. The discrimination test tests the ability of the test person to distinguish odours. The blindfolded test person is given 3 sticks, two of which have the same odour and one a different odour. The test person must determine the odd stick, but is only allowed to smell each stick once. The whole test consists of 16 or 32 triplets [67], [92]. The identification test is similar to the University of Pennsylvania Smell Identification Test (UPSIT) [93]. However, the odours are present in stick form and only 16 or 32 odours are tested [67], [92]. This sub-test can also be done by the patients themselves [94]. After completion of the testing, the results of the 3 individual tests are added together to give a summed value (SDI value). Freeware for carrying out the tests and documenting the results is available (http://wwwold. tu-dresden.de/medkhno/riechen_schmecken/ download.htm).

Extensive smell tests allow differentiation between normosmia, hyposmia and anosmia. The commercial availability of these tests and their standardised use in various centres mean that different clinical tests can be compared. Other recently developed tests are based, for example, on measurement of the sniffing behaviour (e.g. CompuSniff Test: [95]). The clinical value of these tests still has to be evaluated.

\section{Psychophysical testing of retronasal olfaction}

The first clinical assessment of patients that included retronasal test results was carried out by Güttich [96], [97]. The initial goal was to detect malingerers. However, the proposed test was too unstructured and bears little clinical value for the detection of malingerers [98]. There is today a standardised psychophysical test available for studying retronasal olfaction [99], [100]. This involves placing a so-called "Schmeckpulver" (taste powder) in the mouth (20 different powder-form foods and spices, for example cinnamon) and asking the patient to identify the taste from a list of 4 choices. This relatively simple 
test can be prepared by oneself [101]. A very similar test was proposed recently [85]. This test allows for an evaluation of the clinically encountered claim of some patients that he/she has no smell, but that flavour would not be impaired [21].

\section{Electrophysiological procedures to study olfaction}

Objective testing of smell disorders can be performed using olfactory event-related potentials (OERPs) [102]. The olfactometer here must allow presentation of chemical stimuli of defined duration, concentration and stimulus rise time (for details see [103], [104]). If there is an OEP, one can assume that there is an ability to smell. As such, this signal is primarily of importance for medicolegal questions. Psychophysical assessed anosmia does not exclude a residual ability to smell [105], [106]. The latest methods allow the monitoring of the propagation of olfactory activation in the brain on the millisecond scale, meaning that a novel appraisal of smell disorders could be possible [107].

Besides determining OERPs, it is also possible to determine peripheral mucous membrane potentials in humans (so-called electro-olfactograms) directly from the olfactory regions [108]. Although this technique allows to investigate, for example, differences in the processing of individual odours [109], the current clinical value in medico-legal cases or individual patients is limited. This is due to a relatively high inter-individual variability of EOG responses.

\section{Volumetric evaluation of the bulbus olfactorius (BO)}

The $\mathrm{BO}$ is deemed to be the relay station between the peripheral olfactory system and central brain structures. The high plasticity of the BO is maintained by constant neurogenesis, which in turn appears to reflect the degree of afferent neuronal activity. The most obvious effect of olfactory deprivation is a large reduction of the BO volume, for example in those with congenital smell disorders [110], [111], [112], [113]. Supporting evidence for the BO plasticity are recent findings that show, the bulb volume to increase again with improved smell function [114], [115].

The volume of other olfactory-related brain structures also appears to decrease as a function of olfactory loss [116], [117], [118]. The question now, however, is how these findings can be used for the assessment of individual patients.

\section{Functional magnetic resonance imaging (FMRI)}

FMRI uses the so-called BOLD effect (Blood Oxygenation Level Dependent Effect) to measure blood flow changes in the brain. The background is that neuronal activity increases the blood flow in this region. Not only can it be determined when an activation takes place in the brain, but also where this activation takes place [119], [120].
Due to the high variability of the results and non-standardised test protocols, the results attained using this technique have up until now not been able to be routinely used in a clinical setting.

\section{Biopsies from the olfactory regions}

Numerous publications in recent years have described the value of biopsies from the olfactory regions [121], [122], [123]. Although conclusions about groups of patients have been fascinating, there are many unanswered questions about the clinical application to individuals. In other words, unambiguous assignment of a biopsy diagnosis to a functional condition is currently not possible.

\subsection{Treatment of smell disorders}

There are only limited treatments available for smell disorders. A proven effective treatment is only available where nasal illnesses causes the smell disorder (for an overview see [60]). The focus here is on surgical treatment (polypectomy, pansinus procedures) and the application of corticosteroids. With regards to surgical and also non-surgical treatments, the so-called olfactory cleft disease is particularly difficult to treat [78], [124]; this involves isolated swelling in the olfactory cleft area.

\section{Predictive factors}

The prognosis for a smell disorder basically depends on its cause. Age-related and congenital smell disorders cannot be treated successfully. For post-traumatic anosmia, full spontaneous remissions has been observed years after the loss of smell [125]. This is, however rare. In 10 to $20 \%$ of cases of post-traumatic anosmias there is partial remission over the years, whereas the recovery rate is much better for patients with post- infectious olfactory disorders. This figure is about $60 \%$ in cases of post-infection smell disorders. Favourable factors for remission of post-infection or post-trauma anosmia are as high as possible residual ability to smell, female gender, youthful age, non-smoker, initial parosmia, absence of left and right differences in the smell function, and as large as possible amplitudes of the chemosensory evoked potentials to trigeminal stimuli. Also, the duration of the smell disorder is of relevance for the prognosis.

With regards to surgically treated smell disorders, the best results are obtained for women who are aspirin-intolerant in the event of eosinophilia and polyposis. It has to be noted that these patients have severely altered olfactory function before treatment and thus improve a lot after treatment. Age and number of previous operations have little bearing on the success of the operation on the smell disorder. With regards to the smell function, septum operations, for example, only result in significant improvement in $13 \%$ of patients, whilst with paranasal sinus operations this figure is $23 \%$ [126], [127]. The relatively low success rate indicates on the one hand that there is room for improvement and on the other hand that the olfactory 
impairment before surgery is much more moderate than in polyposis patients. Consequently, the olfactory changes are less impressive and less noticed by the patients.

\section{Non-surgical treatment of sinunasal smell disorders}

Corticoids are used as topical and systemic treatments of sinunasal disease [128]. Systemic treatment is accompanied by problematic side-effects, meaning that these drugs are generally not used for longer than 2-3 weeks. An exception is the occasional long-term use of prednisols at a dose of 2-5 mg/d, which is effective for some patients. Most often the use of systemic corticoids is in the form of an intensive course of cortisone, for example starting with a dose of $40 \mathrm{mg}$ (administered at 09:00 in the morning) and then reducing this every second day by $5 \mathrm{mg}$. This procedure also appears useful for idiopathic smell disorders in order to rule out an inflammatory smell disorder, which is not always macroscopically visible. A certain percentage of these patients respond with an improvement in their ability to smell [77], [129].

If these systemic treatments are successful, local corticoids should then be administered. However, there is often no long-term maintenance of the ability to smell [77], [130] with topical steroids alone. A possible cause is that topical steroids do not reach the olfactory cleft due to the filtering function of the nose [131], [132]. It may also be that the inflammation that responds to systemic steroids but not to local steroids is not in the nose but at a level higher, e.g., in the olfactory bulb.

Another approach for non-surgical treatment of sinunasal smell disorders is the local, topical use of Na-citrulline [133], dropped into the olfactory cleft. The results of this first study in normal subjects have never been tried in patients with a double-blind follow-up.

\section{Non-surgical treatment of other smell disorders}

With regard to the treatment of other, non-sinunasal smell disorders, treatments, which are not proven to be efficient include treatment with oestrogens ([134] but see also [50]), zinc [135], [136], [137], minocycline [138], vitamin $A$ at a dose of 10,000 I.E. oral over 4 weeks ([139] - see also [140], [141]).

There are promising approaches but these are also being controversially debated, above all because blinded studies have not been undertaken. These include the use of acupuncture ([142] - see criticism in [143]) and the transcranial magnetic stimulation for parosmia and phantosmia ([144] - see criticism in [145]). Other nonblinded studies report the effectiveness of caroverine for smell disorders. Quint et al. [137] reported significant improvements in smell after a 4 week course of caroverine, an NMDA antagonist which is also used for treating tinnitus. In a further study Hummel et al. [146] showed that alpha lipoic acid also had a positive effect for patients with post-infection smell disorders. Other concepts include utilizing the effectiveness of phosphodiesterase inhibitors such as pentoxifylline [147] or theophylline [148]. Hirsch et al. [149] published results of pilot experiments on the effectiveness of a series of medicines. Although none of these pilot studies was convincing, however the publication put forward a number of interesting proposals for future studies. In a more recent study the effectiveness of smell training [150] showed promising results. The simple instruction to patients is to smell 4 different odours each morning and each evening for a period of 4-6 months; the instruction is not to sniff as often as possible. The so-called odour gymnastics result in improvements in about $25 \%$ of patients. In contrast, an improvement of only about $7 \%$ was found in patients who do not carry out such training.

Many of these studies are promising. In general, however, the mentioned studies are not able to separate the effect of the treatment from possible partial spontaneous remission. Blinded studies in large groups of patients are required for this.

More can be speculated about the future. The autologous replanting of previously removed and amplified olfactory cells appears possible, as does the local use of growth factors and the use of electronic sensors and their attachment to the olfactory bulb. All these ideas are based on the plasticity of the olfactory system.

\section{The sense of taste}

\subsection{Physiology}

Gustatory receptor cells are present in the taste buds, which in turn are in the macroscopically visible tongue papillae. Taste cells, being primary sense cells, are able to regenerate and have a half-life of about 15 days [151], [152]. The receptor cells on the base of the taste buds are innervated by afferent neurons. One individual taste bud can be innervated by several afferent neurons - a single afferent neuron can however also innervate several taste buds (for overview see [153]).

The transduction of acid stimuli occurs by blocking of the $\mathrm{K}^{+}$-channels in the membrane of taste receptors. A potential-independent $\mathrm{Na}^{+}$-channel is involved in the transduction process for salty stimuli. In contrast, the transduction of sweet and bitter stimuli is associated with specific membrane receptors which are coupled to second-messenger systems (CAMP and $\mathrm{IP}_{3}$ ) (for overview see [153]). Interestingly, there are about 30 different bitter receptors, which is indicative of the importance of this system [154]! Taste sensations are transported via 3 cranial nerves: (1) The sensory branch of the intermediate nerve (N. Facialis) that innervates taste receptors on the anterior third of the tongue (chorda tympani) and the palate (N. petrosus superficialis); (2) The N. glossopharyngeus innervates taste receptors on the back of the tongue; (3) The $\mathrm{N}$. vagus ( $\mathrm{N}$. laryngeus superior) innervates taste receptors in the oropharynx and the pharyngeal portion of the epiglottis. There are however also taste receptors in the small intestine [155]. In addition, the N. trigeminus is 
also involved with the transfer of sensations such as the temperature, texture and "hotness" of food (e.g. pepper). This redundancy is probably the reason why the loss of the ability to taste is rarer than loss of smell and indicates the importance of this system. For the processing of the taste information by the central nervous system, very high importance is attached to the brain stem, the thalamus and the anterior insula.

Taste sensitivity diminishes with age, but less strongly than smell sensitivity [156]. As is the case with smell, women are more sensitive to taste than men [157]. Factors such as saliva secretion play a key role for taste [158]. Taste is very closely connected with the retronasal perception of odours [159].

\subsection{Definition of gustatory disorders}

Ageusia is a complete loss of the ability to taste, and hypogeusia a partial loss of the ability to taste. Hypergeusia refers to enhanced gustatory sensitivity. Ageusia is very rare due to the redundant gustatory innervation of the tongue. Of the patients who go to special clinics for their smell or taste disorders, only about $5 \%$ of them actually have a measurable taste impairment [50]. In a recent survey in 761 volunteers (age range 5-89 years) there was no case of ageusia [160]. Interestingly, a one-sided ageusia, for example after severing the chorda tympani or a tumour, is only rarely reported by the patient but regularly found if taste function is measured on each side [161], [162].

The most common taste disorder by far is dysgeusia, an impaired taste sensation, which occurs in about 34\% of all patients going to clinics for people with smell and taste disorders [50]. Taste stimuli are perceived differently than normal, and often as metallic or bitter. Taste and/or smell hallucinations have been described for epilepsies and schizophrenias; sweet dysgeusia sometimes reflects a first sign of lung tumours [163].

\subsection{Aetiology of taste disorders}

Only about $5 \%$ of all patients who visit special clinics for smell and taste disorders actually suffer from taste disorders. The vast majority have smell disorders due to altered odour perception [50]. The main causes of taste disorders are (1) head trauma, (2) infections of the upper respiratory tract, (3) exposure to toxic substances, (4) iatrogenic causes (e.g. dental treatment or exposure to radiation), (5) medicines and (6) glossodynia, the "Burning Mouth Syndrome" (BMS).

Head trauma can cause lesions in the regions of the central nervous system that are important for processing taste stimuli, for example the thalamus, brain stem and the ventral temporal lobes. Furthermore, fractures of the temporal bones or mandible can lead to damage to the $\mathrm{N}$. facialis, whilst the $\mathrm{N}$. glossopharyngeus and $\mathrm{N}$. vagus are relatively well protected deep in the neck [164]. Even on severing the chorda tympani there is complete recovery of taste perception after several months in $20 \%$ of cases [165]. Many medicines can cause taste disorders (see Table 4), with most of the mechanisms involved still being unclear (see for example [166], [167]).

BMS is regularly associated with hypogeusia, and often there is a lasting bitter or metallic taste (for overview see [168]). BMS is most prevalent amongst post-menopausal women - but only very limited success has been achieved with hormone replacement therapy [169]. In about half of cases there was spontaneous partial remission within 6 years of the onset of the illness. Other causes of taste disorders include tumours, bulimia, hypothyreoidismus, Cushing's syndrome, diabetes mellitus and liver disease, poor oral hygiene and the use of mouth rinses [170].

\subsection{Patient examination}

When examining patients with taste disorders, special attention should be put on examining the oral cavity, the ears and the chorda tympani. The anamnesis must ask about the patient's dental hygiene, saliva flow and ability to taste. Questions about swellings, chewing behaviour, pain in the mouth region, ear infections, oral hygiene and associated diseases must also be asked. Examinations using imaging techniques to rule out or prove the presence of damage to central nervous structures, and in particular to the brain stem, thalamus and pons, may be necessary [171]. If bacterial or mycological diseases are suspected, swab tests should be carried out.

\subsection{Testing the ability to taste}

Tests are available which either assess the ability to taste in the whole oral cavity (whole mouth test) or in specific regions (regional test). The tests are often carried out by presenting liquid stimuli to the front or back of the tongue [172]. Other test methods are based on presenting the stimuli in form of a tastant-saturated filter paper [173] or so-called taste strips [174], [175] which is a filter paper test with the dried tastants. The latter have the advantage of a long shelf life; a threshold-like measurement is recorded by presenting taste strips of different concentrations - the task of the patient is to identify the flavour/taste. Whole mouth tests correspond better to the everyday situation for tasting. Small amounts of the flavour solution are kept for a few seconds in the mouth. They are not swallowed but are spat out (sip and spit method [176]). Sugar (sweet), citric acid (acid), sodium chloride (salty) and caffeine or quinine (bitter) are normally used as the stimuli. Umami testing has up until now not been successful. Also popular is the "three drop test" according to Henkin [177], [172]. In this test, three drops of liquid are presented to the patient. One of the drops is the taste stimulus, and the other two drops are of pure water. The threshold is defined as the concentration at which the patient identifies the taste correctly three times in a row. Electrogustometry is based on induction of taste perceptions by passing anodal current to the tongue. The sensation is similar to that if one licks the poles of a battery. The poor correlation between electrically and chemically 
Table 4: Medicines which may cause taste disorders

\begin{tabular}{|l|l|}
\hline Group & Examples \\
\hline Antibiotics, Antimycotics & $\begin{array}{l}\text { Ampicillin, cefamandole, tetracycline, bleomycin, lincomycin, ethambutol, amphotericin } \\
\text { B, griseovulvin, metronidazole, terbinafine }\end{array}$ \\
\hline Antiepileptics & Carbamazepine, phenytoin \\
\hline Antihistamines & Chlorpheniramine, trifluoperazine \\
\hline Immunosuppressants & Doxorubicin, methotrexate, azathioprine, vincristine \\
\hline Antirheumatic drugs & Gold, phenylbutazone \\
\hline Antiseptic agents & Hexetidine \\
\hline Antithyroid drugs & Thiouracil, methimazole, carbimazole \\
\hline Corticosteroids & Dexamethasone, hydrocortisone \\
\hline $\begin{array}{l}\text { Diuretics, } \\
\text { Antihypertensives }\end{array}$ & Acetazolamide, amiloride, captopril, diazoxide, diltiazem, enalapril, nifedipine \\
\hline Antidiabetics & Glipizide, phenformin \\
\hline Local anaesthetics & Tetracaine, benzocaine, lidocaine \\
\hline $\begin{array}{l}\text { Muscle relaxants, } \\
\text { Antiparkinson drugs }\end{array}$ & Baclofen, chlormezanone, L-DOPA \\
\hline Psychopharmaceuticals & Amphetamines, psilocybin \\
\hline Vasodilators & Dipyridamole, nitroglycerin \\
\hline Other & Allopurinol, colchicine, etidronate, iron, phenindione, lithium \\
\hline
\end{tabular}

induced taste perception [178] limits its clinical use for objective taste testing.

Gustatory evoked potentials can also be determined for objective examination [179], and this is particularly useful for medico-legal investigations. Functional MRT possibly also has a certain role to play here [180]. The use of local anaesthetics can be helpful for the diagnosis (and possibly also treatment) of dysgeusia: If the impaired taste sensation disappears after removing the sensory function of a specific area of the tongue, then an impairment of peripheral structures must be the suspected.

\subsection{Treatment of taste disorders}

Special attention must be put on possible underlying illnesses and on medicines taken by the patient (see Table 4). That apart, there are no clear therapeutic guidelines for disorders of the taste function. Treatments with corticoids and vitamin A are often attempted, but there is a lack of convincing clinical studies (see [135]). The same applies for studies involving acupuncture [181]. Only for zinc gluconate (140 mg/d for 3 months) data is available on the therapeutic effectiveness in idiopathic dysgeusia [182], [183]. For BMS, tricyclic antidepressants (amitryptyline, imipramine) appear to improve the abnormal sensation [184]. Successful treatments have been also carried out with clonazepam or diazepam [185]; Gabapentin appears to be ineffective [186].

\section{Summary and outlook}

Smell and taste disorders can markedly affect the quality of life. In recent years validated and reliable methods have been developed for testing the ability to smell and taste, and these methods allow detailed investigation of these senses. Although some of the methods are very simple, they would, for example, allow determination of the ability to smell and taste for quality control purposes, both before and after surgical procedures. Even though a few treatments currently exist, blinded studies are absolutely necessary in order to separate the effect of a treatment from the spontaneous remission of smell and taste disorders. Of special importance for the treatment is the ability of the olfactory epithelium to regenerate.

\section{Further reading}

Leitlinien der Arbeitsgemeinschaft Olfaktologie und Gustologie der Deutschen HNO Gesellschaft:

http://www.tu-dresden.de/medkhno/riechen_ schmecken/LL_Riechen.pdf plus

http://www.tu-dresden.de/medkhno/riechen_ schmecken/LL_Schmecken.pdf

Doty RL. Handbook of Olfaction and Gustation: Second Edition, Revised and Expanded (Neurological Disease and Therapy). Informa Healthcare. 2003.

Hummel T, Welge-Lüssen, eds. Riech- und Schmeckstörungen. Stuttgart: Georg Thieme Verlag KG; 2009.

\section{References}

1. Stevenson RJ. An initial evaluation of the functions of human olfaction. Chem Senses. 2010;35:3-20. DOI: 10.1093/chemse/bjp083 
2. Miwa T, Furukawa M, Tsukatani T, Costanzo RM, DiNardo LJ, Reiter ER. Impact of olfactory impairment on quality of life and disability. Arch Otolaryngol Head Neck Surg. 2001;127:497-503.

3. Temmel AF, Quint C, Schickinger-Fischer B, Klimek L, Stoller E, Hummel T. Characteristics of olfactory disorders in relation to major causes of olfactory loss. Arch Otolaryngol Head Neck Surg. 2002;128:635-641.

4. Santos DV, Reiter ER, DiNardo L, Costanzo RM. Hazardous events associated with impaired olfactory function. Arch Otolaryngol Head Neck Surg. 2004;130:317-319. DOI: 10.1001/archotol.130.3.317

5. Frasnelli J, Hummel T. Olfactory dysfunction and daily life. Eur Arch Otolaryngol. 2005;262:231-238. DOI: 10.1007/s00405004-0796-y

6. Murphy C, Schubert CR, Cruickshanks KJ, Klein BE, Klein R, Nondahl DM. Prevalence of olfactory impairment in older adults. Jama. 2002;288:2307-2312. DOI: 10.1001/jama.288.18.2307

7. Brämerson A, Johansson L, Ek L, Nordin S, Bende M. Prevalence of olfactory dysfunction: The Skövde population-based study. Laryngoscope. 2004;114:733-737. DOI: 10.1097/00005537200404000-00026

8. Landis BN, Konnerth CG, Hummel T. A study on the frequency of olfactory dysfunction. Laryngoscope. 2004;114:1764-1769. DOI: 10.1097/00005537-200410000-00017

9. Vennemann MM, Hummel T, Berger K. The association between smoking and smell and taste impairment in the general population. J Neurol. 2008;255:1121-1126. DOI: 10.1007/s00415-008-0807-9

10. Doty RL, Shaman P, Applebaum SL, Giberson R, Sikorski L, Rosenberg L. Smell identification ability: changes with age. Science. 1984;226:1441-1443. DOI: 10.1126/science.6505700

11. Mackay-Sim A, Johnston AN, Owen C, Burne TH. Olfactory ability in the healthy population: Reassessing presbyosmia. Chem Senses. 2006;31:763-771. DOI: 10.1093/chemse/bjI019

12. Wilson RS, Yu L, Bennett DA. Odor identification and mortality in old age. Chem Senses. 2011 Jan;36(1):63-7. DOI: 10.1093/chemse/bjq098

13. Kobal G. Process for measuring sensory qualities and apparatus therefor. United States patent US 4,681,121. 1987 Jul 21.

14. Witt M, Hummel T. Vomeronasal versus olfactory epithelium: Is there a cellular basis for human vomeronasal perception? Int Rev Cytol. 2006;248C:209-259. DOI: 10.1016/S00747696(06)48004-9

15. Frasnelli J, Lundström JN, Boyle JA, Katsarkas A, Jones-Gotman $M$. The vomeronasal organ is not involved in the perception of endogenous odors. Hum Brain Mapp. 2011 Mar;32(3):450-60. DOI: 10.1002/hbm.21035

16. Schwanzel-Fukuda M, Pfaff DW. Structure and function of the nervus terminalis. In: Doty RL, ed. Handbook of olfaction and gustation. New York: Marcel Dekker; 1995. P. 835-854.

17. Delank KW, Stoll W. Die Riechfunktion vor und nach endonasaler Operation der chronisch-polypösen Sinusitis. HNO. 1994;42:619623.

18. Zhao K, Scherer PW, Hajiloo SA, Dalton P. Effect of anatomy on human nasal air flow and odorant transport patterns: implications for olfaction. Chem Senses. 2004;29:365-379. DOI: 10.1093/chemse/bjh033

19. Damm M, Vent J, Schmidt M, Theissen P, Eckel HE, Lotsch J, Hummel T. Intranasal volume and olfactory function. Chem Senses. 2002;27:831-839. DOI: 10.1093/chemse/27.9.831

20. Pfaar $\mathrm{O}$, Hüttenbrink KB, Hummel T. Assessment of olfactory function after septoplasty: A longitudinal study. Rhinology. 2004;42:195-199.
21. Landis BN, Frasnelli J, Reden J, Lacroix JS, Hummel T. Differences between orthonasal and retronasal olfactory functions in patients with loss of the sense of smell. Arch Otolaryngol Head Neck Surg. 2005;131:977-981. DOI: 10.1001/archotol.131.11.977

22. Konstantinidis I, Triaridis S, Triaridis A, Petropoulos I, Karagiannidis K, Kontzoglou G. How do children with adenoid hypertrophy smell and taste? Clinical assessment of olfactory function pre- and post-adenoidectomy. Int J Pediatr Otorhinolaryngol. 2005 69:1343-1349. DOI: 10.1016/j.ijporl.2005.03.022

23. Moulton DG. Dynamics of cell populations in the olfactory epithelium. Ann NY Acad Sci. 1974;237:52-61. DOI: 10.1111/j.1749-6632.1974.tb49843.x

24. Gradziadei PPC, Monti-Graziadei GA. Continuous nerve cell renewal in the olfactory system. In: Jacobson M, ed. Handbook of sensory physiology. Vol 9. New York: Springer; 1978. P. 55.

25. BreipohI W, Mackay-Sim A, Grandt D, Rehn B, Darrelmann C Neurogenesis in the vertebrate main olfactory epithelium. In: BreipohI W, ed. Ontogeny of olfaction. Berlin: Springer; 1986. P. 21-37. DOI: 10.1007/978-3-642-71576-1_2

26. Nakamura H, Fujiwara M, Kawasaki M, Nonomura N, Takahashi S. Age-related changes in dividing cells of the olfactory epithelium of the maturing guinea pig. Eur Arch Otorhinolaryngol. 1998;255:289-292. DOI: 10.1007/s004050050061

27. Paik SI, Lehman MN, Seiden AM, Duncan HJ, Smith DV. Human olfactory biopsy: the influence of age and receptor distribution. Arch Otolaryngol. 1992;118:731-738. DOI: 10.1001/archotol.1992.01880070061012

28. Reden J, Mueller A, Mueller C, Konstantinidis I, Frasnelli J, Landis BN, Hummel T. Recovery of olfactory function following closed head injury or infections of the upper respiratory tract. Arch Otolaryngol Head Neck Surg. 2006;132:265-269. DOI: 10.1001/archotol.132.3.265

29. Ohloff G. Riechstoffe und Geruchssinn. Berlin: Springer Verlag; 1990.

30. Bignetti E, Cavaggioni A, Pelosi P, Presaud KC, Sorbi RT, Tirindelli R. Purification and characterization of an odorant-binding protein from cow nasal tissue. Eur J Biochem. 1985;149:227-231. DOI: 10.1111/j.1432-1033.1985.tb08916.x

31. Briand L, Eloit C, Nespoulous C, Bezirard V, Huet JC, Henry C, Blon F, Trotier D, Pernollet JC. Evidence of an odorant-binding protein in the human olfactory mucus: location, structural characterization, and odorant-binding properties. Biochemistry. 2002; 41:7241-7252. DOI: 10.1021/bi015916c

32. Federico G, Maremmani C, Cinquanta L, Baroncelli GI, Fattori B, Saggese G. Mucus of the human olfactory epithelium contains the insulin-like growth factor-I system which is altered in some neurodegenerative diseases. Brain Res. 1999;835:306-314. DOI: 10.1016/S0006-8993(99)01614-5

33. Buck L, Axel R. A novel multigene family may encode odorant receptors: a molecular basis for odor recognition. Cell. 1991;65:175-187. DOI: 10.1016/0092-8674(91)90418-X

34. Firestein S. How the olfactory system makes sense of scents. Nature. 2001;413:211-218. DOI: 10.1038/35093026

35. Larsson M, Backman L. Modality memory across the adult life span: evidence for selective age-related olfactory deficits. Exp Aging Res. 1998;24:63-82. DOI: 10.1080/036107398244364

36. Gottfried JA. Smell: central nervous processing. Adv Otorhinolaryngol. 2006;63:44-69. DOI: 10.1159/000093750

37. Shepherd GM. Perspectives on olfactory processing, conscious perception, and orbitofrontal cortex. Ann N Y Acad Sci. 2007;1121:87-101. DOI: 10.1196/annals.1401.032 
38. Doty RL, Cameron EL. Sex differences and reproductive hormone influences on human odor perception. Physiol Behav. 2009;97:213-228. DOI: 10.1016/j.physbeh.2009.02.032

39. Huttenbrink KB. Riech- und Schmeckstörungen: Bewährtes und Neues zu Diagnostik und Therapie. Laryngorhinootologie. 1997;76:506-514. DOI: 10.1055/s-2007-997469

40. Almkvist O, Berglund B, Nordin S. Odor detectability in successfully aged elderly and young adults. Reports from the Dept of Psychology, Stockholm University. 1992;744:1-12.

41. Landis BN, Hummel T, Hugentobler M, Giger R, Lacroix JS. Ratings of overall olfactory function. Chem Senses. 2003;28:691-694. DOI: $10.1093 /$ chemse/bjg061

42. Shu $\mathrm{CH}$, Hummel T, Lee PL, Chiu CH, Lin SH, Yuan BC. The proportion of self-rated olfactory dysfunction does not change across the life span. Am J Rhinol Allergy. 2009;23:413-416. DOI: 10.2500/ajra.2009.23.3343

43. Amoore JE. Specific anosmias. In: Getchell TV, et al, eds. Smell and taste in health and disease. New York: Raven Press; 1991. P. 655-664.

44. Menashe I, Man O, Lancet D, Gilad Y. Different noses for different people. Nat Genet. 2003;34:143-144. DOI: 10.1038/ng1160

45. Henkin RI. Hyperosmia and depression following exposure to toxic vapors. JAMA. 1990;264:2803. DOI: 10.1001/jama.264.21.2803

46. Blau JN, Solomon F. Smell and other sensory disturbances in migraine. J Neurol. 1985;232:275-276. DOI: 10.1007/BF00313864

47. Leopold D. Distortion of olfactory perception: diagnosis and treatment. Chem Senses. 2002;27:611-615. DOI: 10.1093/chemse/27.7.611

48. Hummel T, Welge-Luessen A. Erfassung des Riech- und Schmeckvermögens. In: Hummel T, Welge-Luessen A, eds. Riechund Schmeckstörungen. Stuttgart: Georg Thieme Verlag KG; 2009. P. 43-59.

49. Landis BN, Frasnelli J, Croy I, Hummel T. Evaluating the clinical usefulness of structured questions in parosmia assessment. Laryngoscope. 2010;120:1707-1713. DOI: 10.1002/lary.20955

50. Deems DA, Doty RL, Settle RG, Moore-Gillon V, Shaman P, Mester AF, Kimmelman CP, Brightman VJ, Snow JBj. Smell and taste disorders: a study of 750 patients from the University of Pennsylvania Smell and Taste Center. Arch Otorhinolaryngol Head Neck Surg. 1991;117:519-528. DOI: 10.1001/archotol.1991.01870170065015

51. Gudziol H, Rahneberg K, Burkert S. Anosmiker schmecken schlechter als Gesunde [Anosmics are more poorly able to taste than normal persons]. Laryngorhinootologie. 2007 Sep;86(9):640-3. DOI: 10.1055/s-2007-966228

52. Landis BN, Scheibe M, Weber C, Berger R, Brämerson A, Bende $\mathrm{M}$, Nordin S, Hummel T. Chemosensory interaction: acquired olfactory impairment is associated with decreased taste function. J Neurol. 2010;257:1303-1308. DOI: 10.1007/s00415-0105513-8

53. Stinton N, Atif MA, Barkat N, Doty RL. Influence of smell loss on taste function. Behav Neurosci. 2010;123:256-264. DOI: 10.1037/a0018766

54. Delank KW, Fechner G. Zur Pathophysiologie der posttraumatischen Riechstörungen. Laryngol Rhinol Otol. 1996;75:154-159. DOI: 10.1055/s-2007-997554

55. Rombaux P, Mouraux A, Bertrand B, Nicolas G, Duprez T, Humme T. Retronasal and orthonasal olfactory function in relation to olfactory bulb volume in patients with posttraumatic loss of smell. Laryngoscope. 2006;116:901-905. DOI: 10.1097/01.mlg.0000217533.60311.e7
56. Yamagishi M, Fujiwara M, Nakamura $\mathrm{H}$. Olfactory mucosal findings and clinical course in patients with olfactory disorders following upper respiratory viral infection. Rhinology. 1994;32:113-118.

57. Konstantinidis I, Haehner A, Frasnelli J, Reden J, Quante G, Damm M, Hummel T. Post-infectious olfactory dysfunction exhibits a seasonal pattern. Rhinology. 2006;44:135-139.

58. Suzuki M, Saito K, Min WP, Vladau C, Toida K, Itoh H, Murakami S. Identification of viruses in patients with postviral olfactory dysfunction. Laryngoscope. 2007;117:272-277. DOI: 10.1097/01.mlg.0000249922.37381.1e

59. Delank KW, Stoll W. Pre- and postoperative olfactory function in patients with chronic sinusitis and nasal polyposis. HNO. 1994;42:619-623.

60. Seiden AM. Olfactory loss secondary to nasal and sinus pathology. In: Seiden AM, ed. Taste and smell disorders. New York: Thieme; 1997. P. 52-71.

61. Kesslak JP, Cotman CW, Chui HC, van den Noort S, Fang $\mathrm{H}$, Pfeffer R, Lynch G. Olfactory tests as possible probes for detecting and monitoring Alzheimer's disease. Neurobiol Aging. 1988;9:399-403. DOI: 10.1016/S0197-4580(88)80087-3

62. Ponsen MM, Stoffers D, Booij J, van Eck-Smit BL, Wolters EC, Berendse HW. Idiopathic hyposmia as a preclinical sign of Parkinson's disease. Ann Neurol. 2004;56:173-181. DOI: 10.1002/ana.20160

63. Haehner A, Boesveldt S, Berendse HW, Mackay-Sim A, Fleischmann J, Silburn PA, Johnston AN, Mellick GD, Herting B, Reichmann H, Hummel T. Prevalence of smell loss in Parkinson's disease - a multicenter study. Parkinsonism Relat Disord. 2009;15:490-494. DOI: 10.1016/j.parkreldis.2008.12.005

64. Ansari KA, Johnson A. Olfactory function in patients with Parkinson's disease. J Chron Dis. 1975;28:493-497. DOI: 10.1016/0021-9681(75)90058-2

65. Doty RL, Deems D, Steller S. Olfactory dysfunction in Parkinson's disease: A general deficit unrelated to neurologic signs, disease stage, or disease duration. Neurology. 1988;38:1237-1244.

66. Haehner A, Hummel T, Hummel C, Sommer U, Junghanns S, Reichmann $\mathrm{H}$. Olfactory loss may be a first sign of idiopathic Parkinson's disease. Mov Disorders. 2007;22:839-842. DOI: 10.1002/mds. 21413

67. Hummel T, Kobal G, Gudziol H, Mackay-Sim A. Normative data for the "Sniffin' Sticks" including tests of odor identification, odor discrimination, and olfactory thresholds: an upgrade based on a group of more than 3,000 subjects. Eur Arch Otorhinolaryngol. 2007;264:237-243. DOI: 10.1007/s00405-006-0173-0

68. Braak H, Del Tredici K, Rub U, de Vos RA, Jansen Steur EN, Braak E. Staging of brain pathology related to sporadic Parkinson's disease. Neurobiol Aging. 2003;24:197-211. DOI: 10.1016/S0197-4580(02)00065-9

69. Ross GW, Petrovitch H, Abbott R, Tanner CM, Popper J, Masaki K, Launer L, White LR. Association of olfactory dysfunction with risk for future Parkinson's disease. Ann Neurol. 2008;63:167173.

70. Westermann B, Wattendorf E, Schwerdtfeger U, Husner A, Fuhr P, Gratzl O, Hummel T, Bilecen D, Welge-Lüssen A. Functional imaging of the cerebral olfactory system in patients with Parkinson's disease. J Neurol Neurosurg Psychiatry. 2008;79:1924. DOI: $10.1136 /$ jnnp.2006.113860

71. Wenning GK, Shephard B, Hawkes C, Petruckevitch A, Lees A, Quinn N. Olfactory function in atypical parkinsonian syndromes. Acta Neurol Scand. 1995;91:247-250. DOI: 10.1111/j.16000404.1995.tb06998.x 
72. Welge-Lüssen A, Wattendorf E, Schwerdtfeger U, Fuhr P, Bilecen D, Hummel T, Westermann B. Olfactory-induced brain activity in Parkinson's disease relates to the expression of event-related potentials: a functional magnetic resonance imaging study. Neuroscience. 2009;162:537-543. DOI: 10.1016/j.neuroscience.2009.04.050

73. Nordin S, Paulsen JS, Murphy C. Sensory- and memory-mediated olfactory dysfunction in Huntington's disease. J Int Neuropsycho Soc. 1995;1:281-290. DOI: 10.1017/S1355617700000278

74. Mesholam RI, Moberg PJ, Mahr RN, Doty RL. Olfaction in neurodegenerative disease: a meta-analysis of olfactory functioning in Alzheimer's and Parkinson's diseases. Arch Neurol. 1998;55:84-90. DOI: 10.1001/archneur.55.1.84

75. Hawkes C. Olfaction in neurodegenerative disorder. Adv Otorhinolaryngol. 2006;63:133-151. DOI: 10.1159/000093759

76. Wilson RS, Arnold SE, Schneider JA, Boyle PA, Buchman AS Bennett DA. Olfactory impairment in presymptomatic Alzheimer's disease. Ann N Y Acad Sci. 2009;1170:730-735. DOI: 10.1111/j.1749-6632.2009.04013.x

77. Heilmann S, Hüttenbrink KB, Hummel T. Local and systemic administration of corticosteroids in the treatment of olfactory loss. Am J Rhinol. 2004;18:29-33.

78. Biacabe B, Faulcon P, Amanou L, Bonfils P. Olfactory cleft disease: an analysis of 13 cases. Otolaryngol Head Neck Surg. 2004;130:202-208. DOI: 10.1016/j.otohns.2003.09.002

79. Damm M, Eckel HE, Streppel M, Jungehülsing M, Stennert E. Abhängigkeit des uni- und bilateralen Riechvermögens von der nasalen Strömung bei Patienten mit chronischer Rhinosinusitis. HNO. 2000;48:436-443. DOI: 10.1007/s001060050594

80. Gudziol H, Forster G. Zur Durchführung präoperativer Riechtests aus medicolegaler Sicht. Laryngorhinootologie. 2002;81:586590. DOI: $10.1055 / \mathrm{s}-2002-33360$

81. Hummel T, Sekinger B, Wolf S, Pauli E, Kobal G. "Sniffin' Sticks": Olfactory performance assessed by the combined testing of odo identification, odor discrimination and olfactory threshold. Chem Senses. 1997;22:39-52. DOI: 10.1093/chemse/22.1.39

82. Kobal G, Klimek L, Wolfensberger M, Gudziol H, Temmel A, Owen $\mathrm{CM}$, Seeber H, Pauli E, Hummel T. Multicenter investigation of 1,036 subjects using a standardized method for the assessment of olfactory function combining tests of odor identification, odor discrimination, and olfactory thresholds. Eur Arch Otorhinolaryngol. 2000;257:205-211. DOI: $10.1007 / \mathrm{s} 004050050223$

83. Hummel T, Konnerth CG, Rosenheim K, Kobal G. Screening of olfactory function with a four-minute odor identification test: reliability, normative data, and investigations in patients with olfactory loss. Ann Otol Rhinol Laryngol. 2001;110:976-981.

84. Hummel T, Pfetzing U, Lötsch J. A short olfactory test based on the identification of three odors. J Neurol. 2010; 257:1316-1321. DOI: $10.1007 / \mathrm{s} 00415-010-5516-5$

85. Mueller C, Renner B. A new procedure for the short screening of olfactory function using five items from the "Sniffin' Sticks" identification test kit. Am J Rhinol. 2006;20:113-116.

86. Royet JP, Hudry J, Zald DH, Godinot D, Gregoire MC, Lavenne F, Costes N, Holley A. Functional neuroanatomy of different olfactory judgments. Neuroimage. 2001;13:506-519. DOI: 10.1006/nimg.2000.0704

87. Lötsch J, Reichmann H, Hummel T. Different odor tests contribute differently to the diagnostics of olfactory loss. Chem Senses. 2008;33:17-21.

88. Hedner M, Larsson M, Arnold N, Zucco GM, Hummel T. Cognitive factors in odor detection, odor discrimination, and odor identification tasks. J Clin Exp Neuropsychol. 2010;30:1-6.
89. Doty RL, Smith R, McKeown DA, Raj J. Tests of human olfactory function: principle component analysis suggests that most measure a common source of variance. Percept Psychophys. 1994;56:701-707. DOI: 10.3758/BF03208363

90. Doty RL, McKeown DA, Lee WW, Shaman P. A study of the testretest reliability of ten olfactory tests. Chem Senses. 1995;20:645-656. DOI: 10.1093/chemse/20.6.645

91. Hummel T, Lange K, Lötsch J. Vergleich neuartiger Riechschwellenbestimmungen mit der „klassischen“ ButanolSchwelle. Proceedings of the "Arbeitsgemeinschaft Olfaktologie/Gustologie der Deutschen HNO Gesellschaft". 2005. Available from: http://wwwold.tu-dresden.de/medkhno/riechen_ schmecken/dessau_2005.htm

92. Haehner A, Mayer AM, Landis BN, Pournaras I, Lill K, Gudziol V, Hummel T. High test-retest reliability of the extended version of the "Sniffin' Sticks" test. Chem Senses.2009;34:705-711. DOI: 10.1093/chemse/bjp057

93. Doty RL, Shaman P, Kimmelman CP, Dann MS. University of Pennsylvania Smell Identification Test: a rapid quantitative olfactory function test for the clinic. Laryngoscope. 1984;94:176178. DOI: 10.1288/00005537-198402000-00004

94. Mueller CA, Grassinger E, Naka A, Temmel AF, Hummel T, Kobal G. A Self-administered Odor Identification Test Procedure Using the "Sniffin' Sticks". Chem Senses. 2006;31:595-598. DOI: 10.1093/chemse/bjj064

95. Frank RA, Gesteland RC, Bailie J, Rybalsky K, Seiden A, Dulay MF. Characterization of the sniff magnitude test. Arch Otolaryngol Head Neck Surg. 2006;132:532-536. DOI: 10.1001/archotol.132.5.532

96. Güttich H. Gustatorische Riechprüfung mit Riechstoffen und Mischreizschmeckstoffen. Arch Ohren Nasen Kehlk Heilk. 1961;178:327-330.

97. Güttich H. Intravenös verabreichte Riechstoffe: Gustatorisches Riechen. HNO. 1965;13:42-45.

98. Hummel T, Rosenheim K, Knecht M, Heilmann S, Murbe D, Hüttenbrink KB. Der gustatorische Riechtest in der Technik nach Güttich: Eine Überprüfung der klinischen Brauchbarkeit. Laryngorhinootologie. 1999;78:627-631. DOI: 10.1055/s-199912978

99. Heilmann S, Strehle G, Rosenheim K, Damm M, Hummel T. Clinical assessment of retronasal olfactory function. Arch Otorhinolaryngol Head Neck Surg. 2002;128:414-418.

100. Heilmann S, Hummel T. A new method for comparing orthonasal and retronasal olfaction. Behav Neurosci. 2004;118:412-419. DOI: 10.1037/0735-7044.118.2.412

101. Leon EA, Catalanotto FA, Werning JW. Retronasal and orthonasal olfactory ability after laryngectomy. Arch Otolaryngol Head Neck Surg. 2007;133:32-36. DOI: 10.1001/archotol.133.1.32

102. Hummel T, Klimek L, Welge-Lussen A, Wolfensberger G, Gudziol $H$, Renner B, Kobal G. Chemosensorisch evozierte Potentiale zur klinischen Diagnostik von Riechstörungen. HNO. 2000;48:481485. DOI: $10.1007 /$ s001060050602

103. Kobal G. Elektrophysiologische Untersuchungen des menschlichen Geruchssinns. Stuttgart: Thieme Verlag; 1981.

104. Hummel T, Klimek L, Welge-Lüssen A, Wolfensberger G, Gudziol H, Renner B, Kobal G. Standards für die Ableitung chemosensorisch evozierter Potentiale zur klinischen Diagnostik von Riechstörungen. HNO. 2000;48:481-485. DOI: $10.1007 / \mathrm{s} 001060050602$

105. Lötsch J, Hummel T. The clinical significance of electrophysiological measures of olfactory function. Behav Brain Res. 2006;170:78-83. DOI: 10.1016/j.bbr.2006.02.013 
106. Rombaux P, Bertrand B, Keller T, Mouraux A. Clinical significance of olfactory event-related potentials related to orthonasal and retronasal olfactory testing. Laryngoscope. 2007;117:10961101. DOI: 10.1097/MLG.0b013e31804d1dOd

107. Lascano AM, Hummel T, Lacroix JS, Landis BN, Michel CM. Spatiotemporal dynamics of olfactory processing in the human brain: an event-related source imaging study. Neuroscience. 2010;167:700-708. DOI: 10.1016/j.neuroscience.2010.02.013

108. Knecht M, Hummel T. Recording of the human electroolfactogram. Physiol Behav. 2004;83:13-19.

109. Lapid H, Schuster B, Schneidman E, Roth Y, Harel D, Sobel N, Hummel T. Odorant identity and concentration effects in electroolfactograms recorded at the human olfactory epithelium. J Neurophysiol. 2009;102:2121-2130. DOI: 10.1152/jn.91321.2008

110. Yousem DM, Geckle RJ, Bilker WB, Doty RL. Olfactory bulb and tract and temporal lobe volumes. Normative data across decades. Ann N Y Acad Sci. 1998;855:546-555. DOI: 10.1111/j.17496632.1998.tb10624.x

111. Yousem DM, Geckle RJ, Bilker WB, Kroger H, Doty RL. Posttraumatic smell loss: relationship of psychophysical tests and volumes of the olfactory bulbs and tracts and the tempora lobes. Acad Radiol. 1999;6:264-272. DOI: 10.1016/S10766332(99)80449-8

112. Abolmaali N, Hummel T, Damm M. Moderne bildgebende Diagnostik bei Riechstörungen. Laryngorhinootologie. 2009;88:10-16. DOI: 10.1055/s-2008-1077630

113. Rombaux P, Duprez T, Hummel T. Olfactory bulb volume in the clinical assessment of olfactory dysfunction. Rhinology. 2009;47:3-9

114. Haehner A, Rodewald A, Gerber JC, Hummel T. Changes of the volume of the human olfactory bulb with olfactory function. Arch ORL. 2008;134:621-624.

115. Gudziol V, Buschhuter D, Abolmaali N, Gerber J, Rombaux P, Hummel T. Increasing olfactory bulb volume due to treatment of chronic rhinosinusitis - a longitudinal study. Brain. 2009;132:3096-3101. DOI: 10.1093/brain/awp243

116. Bitter T, Brüderle J, Gudziol H, Burmeister HP, Gaser C, GuntinasLichius O. Gray and white matter reduction in hyposmic subjects - A voxel-based morphometry study. Brain Res. 2010;1347:4247. DOI: 10.1016/j.brainres.2010.06.003

117. Bitter T, Gudziol H, Burmeister HP, Mentzel HJ, Guntinas-Lichius $\mathrm{O}$, Gaser C. Anosmia leads to a loss of gray matter in cortical brain areas. Chem Senses. 2010;35:407-415. DOI: 10.1093/chemse/bjq028

118. Frasnelli J, Lundstrom JN, Boyle JA, Djordjevic J, Zatorre RJ, JonesGotman M. Neuroanatomical correlates of olfactory performance. Exp Brain Res. 2010;201:1-11. DOI: 10.1007/s00221-0091999-7

119. Gottfried JA, Winston JS, Dolan RJ. Dissociable codes of odor quality and odorant structure in human piriform cortex. Neuron. 2006;49:467-479. DOI: 10.1016/j.neuron.2006.01.007

120. Iannilli E, Gerber J, Frasnelli J, Hummel T. Intranasal trigemina function in subjects with and without an intact sense of smell. Brain Res. 2007;1139:235-244. DOI: 10.1016/j.brainres.2006.12.082

121. Feron F, Perry C, Cochrane J, Licina P, Nowitzke A, Urquhart S, Geraghty T, Mackay-Sim A. Autologous olfactory ensheathing cell transplantation in human spinal cord injury. Brain. 2005;128:2951-2960. DOI: 10.1093/brain/awh657

122. Haxel BR, Murrell WG, Mackay-Sim A. Untersuchungen der Riechschleimhaut von anosmischen Patienten nach SchädelHirn-Trauma. HNO. 2005;53:688-689.
123. Witt M, Bormann K, Gudziol V, Pehlke K, Barth K, Minovi A, Hahner A, Reichmann H, Hummel T. Biopsies of olfactory epithelium in patients with Parkinson's disease. Mov Disord. 2009;24:906-914. DOI: 10.1002/mds.22464

124. Trotier D, Bensimon JL, Herman P, Tran Ba Huy P, Døving KB, Eloit C. Inflammatory obstruction of the olfactory clefts and olfactory loss in humans: a new syndrome? Chem Senses. 2007;32:285-292. DOI: 10.1093/chemse/bjl057

125. Mueller CA, Hummel T. Recovery of olfactory function after nine years: An unusual case report of posttraumatic anosmia. J Med Case Reports. 2009;3:9283. DOI: 10.4076/1752-1947-3-9283

126. Minovi A, Hummel T, Ural A, Draf W, Bockmühl U. Predictors of the outcome of nasal surgery in terms of olfactory function. Eur Arch Otorhinolaryngol. 2007;265:57-62. DOI: 10.1007/s00405007-0409-7

127. Pade J, Hummel T. Olfactory function following nasal surgery. Laryngoscope. 2008;118:1260-1264.

128. Jafek BW, Moran DT, Eller PM, Rowley JC 3rd, Jafek TB. Steroiddependent anosmia. Arch Otolaryngol Head Neck Surg. 1987 May;113(5):547-9. DOI: 10.1001/archotol.1987.01860050093023

129. Heilmann T, Just $T$, Goktas $O$, Hauswald $B$, Hüttenbrink KB, Hummel T. Untersuchung der Wirksamkeit von systemischen bzw. topischen Kortikoiden und Vitamin B bei Riechstörungen. Laryngo-Rhino-Otol. 2004;83:729-734. DOI: 10.1055/s-2004825676

130. Blomqvist EH, Lundblad L, Bergstedt H, Stjarne P. Placebocontrolled, randomized, double-blind study evaluating the efficacy of fluticasone propionate nasal spray for the treatment of patients with hyposmia/anosmia. Acta Otolaryngol. 2003;123:862-868. DOI: $10.1080 / 00016480310002140$

131. Benninger MS, Hadley JA, Osguthorpe JD, Marple BF, Leopold DA, Derebery MJ, Hannley M. Techniques of intranasal steroid use. Otolaryngol Head Neck Surg. 2004;130:5-24. DOI: 10.1016/j.otohns.2003.10.007

132. Scheibe M, Bethge $C$, Witt M, Hummel T. Intranasal administration of drugs. Arch Otolaryngol Head Neck Surg. 2008;134(6):643-6. DOI: 10.1001/archotol.134.6.643

133. Panagiotopoulos G, Naxakis S, Papavasiliou A, Filipakis K, Papatheodorou G, Goumas P. Decreasing nasal mucus Ca++ improves hyposmia. Rhinology. 2005;43:130-134.

134. Hughes LF, McAsey ME, Donathan CL, Smith T, Coney P, Struble RG. Effects of hormone replacement therapy on olfactory sensitivity: cross-sectional and longitudinal studies. Climacteric. 2002;5:140-150.

135. Henkin RI, Schecter PJ, Friedewald WT, Demets DL, Raff M. A double-blind study of the effects of zinc sulfate on taste and smell dysfunction. Am J Med Sci. 1976;272:285-299. DOI: 10.1097/00000441-197611000-00006

136. Alpers $\mathrm{DH}$. Zinc and deficiencies of taste and smell. Jama. 1994;272:1233-1234. DOI: 10.1001/jama.1994.03520160009004

137. Quint C, Temmel AFP, Hummel T, Ehrenberger K. The quinoxaline derivative caroverine in the treatment of sensorineural smell disorders: a proof of concept study. Acta Otolaryngol. 2002;122:877-881. DOI: 10.1080/003655402/000028054

138. Reden J, Herting B, Lill K, Kern R, Hummel T. Treatment of postinfectious olfactory disorders with minocycline: a doubleblind, placebo-controlled study. Laryngoscope. 2011 Mar;121(3):679-82. DOI: 10.1002/lary.21401. 
139. Lill K, Reden J, Müller A, Zahnert T, Hummel T. Olfactory function in patients with post-infectious and post-traumatic smell disorders before and after treatment with vitamin A: a double-blind, placebo-controlled, randomized clincial trial. Chem Senses. 2006;31:A33.

140. Garrett-Laster M, Russell RM, Jacques PF. Impairment of taste and olfaction in patients with cirrhosis: the role of vitamin A. Hum Nutr Clin Nutr. 1984;38:203-214.

141. Duncan H. Postviral olfactory loss. In: Seiden AM, ed. Taste and smell disorders. New York: Thieme; 1997. P. 72-78.

142. Vent J, Wang DW, Damm M. Effects of traditional Chinese acupuncture in post-viral olfactory dysfunction. Otolaryngol Head Neck Surg. 2010;142:505-509. DOI: 10.1016/j.otohns.2010.01.012

143. Silas J, Doty RL. No evidence for specific benefit of acupuncture over vitamin B complex in treating persons with olfactory dysfunction. Otolaryngol Head Neck Surg. 2010;143:603. DOI: 10.1016/j.otohns.2010.07.008

144. Henkin RI, Potolicchio SJ Jr, Levy LM. Improvement in smell and taste dysfunction after repetitive transcranial magnetic stimulation. Am J Otolaryngol. 2011 Jan-Feb;32(1):38-46. DOI: 10.1016/j.amjoto.2009.10.001

145. Silas J, Atif MA, Doty RL. Transcranial magnetic stimulation: a treatment for smell and taste dysfunction. Am J Otolaryngol. 2011 Mar-Apr;32(2):177. DOI: 10.1016/j.amjoto.2010.07.005

146. Hummel T, Heilmann S, Hüttenbrink KB. Lipoic acid in the treatment of smell dysfunction following viral infection of the upper respiratory tract. Laryngoscope. 2002;112:2076-2080. DOI: 10.1097/00005537-200211000-00031

147. Gudziol V, Hummel T. Effects of pentoxifylline on olfactory sensitivity: a postmarketing surveillance study. Arch Otolaryngol Head Neck Surg. 2009;135:291-295. DOI: 10.1001/archoto.2008.524

148. Henkin RI, Velicu I, Schmidt L. An open-label controlled trial of theophylline for treatment of patients with hyposmia. Am J Med Sci. 2009;337:396-406. DOI: 10.1097/MAJ.0b013e3181914a97

149. Hirsch AR, Dougherty DD, Aranda JG, Vanderbilt JG, Weclaw GC. Medications for Olfactory Loss: Pilot Studies. J Neurol Orthop Med Surg. 1996;17:109-114

150. Hummel T, Rissom K, Hähner A, Reden J, Weidenbecher M, Hüttenbrink KB. Effects of olfactory training in patients with olfactory loss. Laryngoscope. 2009;119:496-499. DOI: 10.1002/lary.20101

151. Beidler LM, Smallman RL. Renewal of cells within taste buds. J Cell Bio. 1965;27:263-272. DOI: 10.1083/jcb.27.2.263

152. Srur E, Stachs O, Guthoff R, Witt M, Pau HW, Just T. Change of the human taste bud volume over time. Auris Nasus Larynx. 2010;37:449-455. DOI: 10.1016/j.anl.2009.11.010

153. Chaudhari N, Roper SD. The cell biology of taste. J Cell Biol. 2010;190:285-296. DOI: 10.1083/jcb.201003144

154. Behrens M, Reichling C, Batram C, Brockhoff A, Meyerhof W. Bitter taste receptors and their cells. Ann N Y Acad Sci. 2009;1170:111-115. DOI: 10.1111/j.1749-6632.2009.03897.x

155. Bezençon C, le Coutre J, Damak S. Taste-signaling proteins are coexpressed in solitary intestinal epithelial cells. Chem Senses. 2007;32:41-49.

156. Mojet J, Heidema H, Christ E. Sensitivity to the basic tastes: the effects of age. Chemical Senses. 1996;21:644.

157. Doty RL. Gender and reproductive state correlates of taste perception in humans. In: McGill TE, et al, eds. Sex and behaviour: status and prospectus. New York: Plenum; 1978. P. 337-362.
158. Beidler LM. Saliva. In: Doty RL, ed. Handbook of olfaction and gustation. New York: Marcel Dekker; 1995. P. 503-519.

159. Small DM, Jones-Gotman M, Zatorre RJ, Petrides M, Evans AC. Flavor processing: more than the sum of its parts. Neuroreport. 1997;8:3913-3917. DOI: 10.1097/00001756-19971222000014

160. Welge-Lüssen A, Dörig P, Wolfensberger M, Krone F, Hummel T. A study about the frequency of taste disorders. J Neurol. 2011 Mar;258(3):386-92. DOI: 10.1007/s00415-010-5763-5

161. Grant R, Miller S, Simpson D, Lamey PJ, Bone I. The effect of chorda tympani section on ipsilateral and contralateral salivary secretion and taste in man. J Neurol Neurosurg Psychiatry. 1989;52:1058-1062. DOI: 10.1136/jnnp.52.9.1058

162. Saito T, Manabe $Y$, Shibamori $Y$, Yamagishi T, Igawa $H$, Tokuriki M, Fukuoka Y, Noda I, Ohtsubo T, Saito H. Long-term follow-up results of electrogustometry and subjective taste disorder after middle ear surgery. Laryngoscope. 2001;111:2064-2070. DOI: 10.1097/00005537-200111000-00037

163. Nakazato Y, Imai K, Abe T, Tamura N, Shimazu K. Unpleasant sweet taste: a symptom of SIADH caused by lung cancer. J Neurol Neurosurg Psychiatry. 2006;77:405-406. DOI: 10.1136/jnnp.2005.073726

164. Heckmann JG, Lang CJ. Neurological causes of taste disorders. Adv Otorhinolaryngol. 2006;63:255-264. DOI: $10.1159 / 000093764$

165. Bull TR. Taste and the chorda tympani. J Larnygol Otol. 1965;79:479-493. DOI: 10.1017/S0022215100063969

166. Ackerman BH, Kasbekar N. Disturbances of taste and smell induced by drugs. Pharmacotherapy. 1997;17:482-496.

167. Doty RL, Bromley SM. Effects of drugs on olfaction and taste. Otolaryngol Clin North Am. 2004;37:1229-1254. DOI: 10.1016/j.otc.2004.05.002

168. Grushka M, Epstein JB, Gorsky M. Burning mouth syndrome and other oral sensory disorders: A unifying hypothesis. Pain Res Manag. 2003;8:133-135.

169. Forabosco A, Criscuolo M, Coukos G, Uccelli E, Weinstein R, Spinato S, Botticelli A, Volpe A. Efficacy of hormone replacement therapy in postmenopausal women with oral discomfort. Oral Surg Oral Med Oral Pathol. 1992;73:570-574. DOI: 10.1016/0030-4220(92)90100-5

170. Landis BN, Just T. Schmeckstörungen. In: Hummel, T, WelgeLuessen A, eds. Riech- und Schmeckstörungen. Stuttgart: Georg Thieme Verlag KG; 2009. P. 95-106.

171. Landis BN, Leuchter I, San Millán Ruíz D, Lacroix JS, Landis T. Transient hemiageusia in cerebrovascular lateral pontine lesions. J Neurol Neurosurg Psychiatry. 2006;77:680-683. DOI: 10.1136/jnnp.2005.086801

172. Gudziol H, Hummel T. Normative values for the assessment of gustatory function using liquid tastants. Acta Otolaryngol. 2007;127:658-661. DOI: 10.1080/00016480600951491

173. Tomita H. Methods in taste examination. In: Surjan L, Bodo G, eds. Proc XIlth ORL World Congr, Budapest, Hungary, 1981. Amsterdam, Oxford: Excerpta Medica; 1982. P. 627.

174. Mueller C, Kallert S, Renner B, Stiassny K, Temmel AF, Humme T, Kobal G. Quantitative assessment of gustatory function in a clinical context using impregnated "taste strips". Rhinology. 2003;41:2-6

175. Landis BN, Welge-Luessen A, Brämerson A, Bende M, Mueller CA, Nordin S, Hummel T. "Taste Strips" - a rapid, lateralized, gustatory bedside identification test based on impregnated filter papers. J Neurol. 2009;256:242-248. DOI: 10.1007/s00415 009-0088-y 
176. Delwiche JF, Halpern BP, Lee MY. A comparison of tip of the tongue and sip and spit screening procedures. Food Qual P. 1996;7:293-297. DOI: 10.1016/S0950-3293(96)00008-0

177. Henkin RI, Gill JR, Bartter FC. Studies on taste thresholds in normal man and in patients with adrenal cortical insufficiency: the role of acrenal cortical steroids and serum sodium concentration. J Clin Invest. 1963;42:727-735. DOI: $10.1172 / \mathrm{JCl} 104765$

178. Murphy C, Quinonez C, Nordin S. Reliability and validity of electrogustometry and its application to young and elderly persons. Chem Senses. 1995;10:499-503. DOI: 10.1093/chemse/20.5.499

179. Hummel T, Genow A, Landis BN. Clinical assessment of human gustatory function using event related potentials. J Neurol Neurosurg Psychiatry. 2010;81:459-464. DOI: 10.1136/jnnp.2009.183699

180. Hummel C, Frasnelli J, Gerber J, Hummel T. Cerebral processing of gustatory stimuli in patients with taste loss. Behav Brain Res. 2007;185:59-64. DOI: 10.1016/j.bbr.2007.07.019

181. Brandt H, Hauswald B, Langer H, Gleditsch J, Zahnert T. Wirksamkeit der Akupunktur bei der Therapie von idiopathischen Schmeckstörungen. Dt Zeitschr Akupunktur. 2008;51:24-31.

182. Heckmann SM, Hujoel P, Habiger S, Friess W, Wichmann M, Heckmann JG, Hummel T. Zinc gluconate in the treatment of dysgeusia - a randomized clinical trial. J Dent Res. 2005;84:35 38. DOI: $10.1177 / 154405910508400105$

183. Sakagami M, Ikeda M, Tomita H, Ikui A, Aiba T, Takeda N, Inokuchi A, Kurono Y, Nakashima M, Shibasaki Y, Yotsuya O. A zinc-containing compound, Polaprezinc, is effective for patients with taste disorders: randomized, double-blind, placebocontrolled, multi-center study. Acta Otolaryngol. 2008;26:1-6.

184. Barker KE, Batstone MD, Savage NW. Comparison of treatment modalities in burning mouth syndrome. Aust Dent J. 2009; 54:300-305. DOI: 10.1111/j.1834-7819.2009.01154.x
185. Hampf G, Aalberg V, Sunden B. Experiences from a facial pain unit. J Craniomand Cont Dent Ed. 1990;114:267-272.

186. Heckmann SM, Heckmann JG, Ungethum A, Hujoel P, Humme T. Gabapentin has little or no effect in the treatment of burning mouth syndrome - results of an open-label pilot study. Eur J Neurol. 2006;13:e6-e7. DOI: 10.1111/j.1468 1331.2006.01294.x

\section{Corresponding author:}

Prof. Dr. med. Thomas Hummel

HNO Klinik, Universitätsklinikum Dresden, Fetscherstr. 74, 01037 Dresden, Germany, Phone: 0351-458-4189, Fax: 0351-458-4326

thummel@mail.zih.tu-dresden.de

\section{Please cite as}

Hummel T, Landis BN, Hüttenbrink KB. Smell and taste disorders. GMS Curr Top Otorhinolaryngol Head Neck Surg. 2011;10:Doc04.

DOI: 10.3205/cto000077, URN: urn:nbn:de:0183-cto0000772

\section{This article is freely available from}

http://www.egms.de/en/journals/cto/2011-10/cto000077.shtml

Published: 2012-04-26

\section{Copyright}

(C2011 Hummel et al. This is an Open Access article distributed under the terms of the Creative Commons Attribution License (http://creativecommons.org/licenses/by-nc-nd/3.0/deed.en). You are free: to Share - to copy, distribute and transmit the work, provided the original author and source are credited. 